\title{
Corrosion Behaviour of Cu/Carbon Steel Gradient Material
}

\author{
Tao Ma, Huirong Li, Jianxin Gao and Yungang $\mathrm{Li}^{*}$
}

check for

updates

Citation: Ma, T.; Li, H.; Gao, J.; Li, Y. Corrosion Behaviour of $\mathrm{Cu} /$ Carbon Steel Gradient Material. Crystals 2021, 11, 1091. https://doi.org/10.3390/ cryst11091091

Academic Editor: Pavel Lukáč

Received: 4 August 2021

Accepted: 6 September 2021

Published: 7 September 2021

Publisher's Note: MDPI stays neutral with regard to jurisdictional claims in published maps and institutional affiliations.

Copyright: (c) 2021 by the authors. Licensee MDPI, Basel, Switzerland. This article is an open access article distributed under the terms and conditions of the Creative Commons Attribution (CC BY) license (https:/ / creativecommons.org/licenses/by/ $4.0 /)$.
Key Laboratory of Ministry of Education for Modern Metallurgy Technology, College of Metallurgy and Energy, North China University of Science and Technology, Tangshan 063210, China; matao2011@sina.com (T.M.); lihuirong@ncst.edu.cn (H.L.); gjx@ncst.edu.cn (J.G.)

* Correspondence: lyg@ncst.edu.cn

\begin{abstract}
Research on improving the corrosion resistance of carbon steel has become a hot topic in the iron and steel field in recent years. Copper plating on the surface of carbon steel is considered an effective means to improve its corrosion resistance, but the copper-plated carbon steel material prepared by this method has the problems of poor abrasion resistance, easy delamination of copper layer and similar issues, which affect the service performance of the copper-plated carbon steel material. To solve this problem, a new type of material whose surface is copper and the copper element is gradually diffused into carbon steel was developed by a plating-diffusion method, which is defined as a copper-carbon steel gradient material. Carbon steel with a copper plated surface and the $\mathrm{Cu}-\mathrm{Fe}$ /carbon steel gradient material with $80 \% \mathrm{Cu}$ content on the surface were prepared by the same method. The cross-sectional microstructure and composition of different samples were analysed, and the corrosion behaviors of samples in $3.5 \% \mathrm{NaCl}$ solution were studied by the linear polarization curve method and electrochemical impedance spectroscopy. The cross-sectional microstructure result shows that the diffusion of copper in carbon is mainly carried out along its grain boundary, and the diffusion of copper will inhibit the growth of grains during heat treatment. As shown in the results of corrosion behaviors, there is no pitting corrosion in the corrosion process of all samples, as well as the stable passive film. All samples showed active dissolution. Compared with carbon steel, the corrosion potential of the $\mathrm{Cu}$ /carbon steel gradient material becomes more positive from $-600 \mathrm{mV}$ to $-362 \mathrm{mV}$, the corrosion current density decreases from $53.0 \mu \mathrm{A} / \mathrm{cm}^{2}$ to $30.6 \mu \mathrm{A} / \mathrm{cm}^{2}$ and the radius of electrochemical impedance spectroscopy enlarges while the corrosion resistance is improved, and the corrosion resistance is mainly obtained by its surface copper layer. The corrosion resistance of $\mathrm{Cu}-\mathrm{Fe}$ /carbon steel gradient material is lower than that of $\mathrm{Cu} /$ carbon steel gradient material, while it is still better than carbon steel, and it shows a clear passivation trend during corrosion. Therefore, the copper/carbon steel gradient material can significantly improve the corrosion resistance of carbon steel. Even after the surface copper layer is destroyed, the gradient material can protect the matrix and improve the service life of the material.
\end{abstract}

Keywords: $\mathrm{Cu}$; carbon steel; gradient material; electrochemical; corrosion; $\mathrm{Cu}$ /carbon steel composite

\section{Introduction}

Carbon steel has become the most widely used steel in the fields of construction and transportation because of its low cost, simple production process and excellent plasticity, toughness and processability. However, carbon steel is easily corroded and invalidated, which greatly restricts its application in a wider range of fields and brings a lot of economic losses. Therefore, research on improving the corrosion resistance of carbon steel has become a hot topic in the iron and steel field in recent years [1-3]. As a non-ferrous metal element, copper has an obvious effect on improving the corrosion resistance of steel [4-6]. The American Society for Testing and Materials (ASTM) has proved that adding 0.04\% copper to steel can significantly reduce the corrosion rate of steel in the atmosphere. Therefore, the research and development of weathering steel containing copper has been paid more and more attention in recent years. In the 1930s, U.S. Steel took the lead in developing 
Corten-steel [7], a low alloy weathering steel containing copper, which has 4-8 times better atmospheric corrosion resistance than ordinary carbon steel. Since the 1960s, Corten-steel has been directly used in construction, transportation and other fields without painting. At the same time, in order to reduce the economic loss caused by corrosion failure of carbon steel, different types of weathering steel containing copper have been developed, such as WR50A of the United Kingdom, SPA-H of Japan, 09CuPTi of China and so on [8,9]. At present, the production method of weathering steel containing copper is still to add a certain amount of copper or copper alloy in the smelting process, and use the corresponding heat treatment process to promote the precipitation of copper in the steel and obtain weathering steel. On the one hand, this method has a strict production process, and it is easy to cause copper brittleness by improper treatment. On the other hand, as a functional material, the corrosion resistance of weathering steel is mainly reflected by the corrosion resistance of its surface, and the corrosion resistance of weathering steel is weakly affected by the presence or absence of copper in its interior. Therefore, the addition of copper in the smelting process will result in the waste of copper resources and increase the production cost of weathering steel, which also limits the development and application of weathering steel in various fields.

The preparation of copper-plated carbon steel material on the surface of carbon steel by electroplate, hot dipping, mechanical alloying and similar methods can effectively improve the corrosion resistance of carbon steel, simplify the production process, and reduce the consumption of copper raw materials, but the copper-plated carbon steel material prepared by these methods has the problems of poor abrasion resistance, easy delamination of copper layer and similar issues, which affect the service performance of the copper-plated carbon steel material. If the copper-coated carbon steel is treated by diffusion annealing, the copper atoms can be diffused into the carbon steel to form a copper-containing gradient layer by thermal diffusion, and a new type of copper/carbon steel gradient material with a pure copper surface and a copper concentration decreasing with the increase of depth in the carbon steel can be prepared. The copper layer is only prepared on the surface of the carbon steel to improve the corrosion resistance of carbon steel, which not only greatly saves the consumption of copper raw materials, but also realizes the metallurgical combination of copper and carbon stee, and improves the bond strength between copper layer and carbon steel matrix. Because the electroplated copper surface is often worn or corroded during use, the internal gradient diffusion layer is exposed to the surface. Therefore, it is important to study the corrosion resistance difference between the pure copper layer, gradient diffusion layer and carbon steel to predict the use effect of this gradient composite.

At present, there are few reports about the morphology and corrosion resistance of these kinds of gradient materials. Based on this, a layer of copper was deposited on the surface of carbon steel by an electroplating method and then annealed at high temperature to make the copper atoms diffuse into the carbon steel to form a copper-containing gradient layer, and the copper/carbon steel gradient material was prepared. Based on the previous work, the corrosion behavior of the graded materials in $3.5 \% \mathrm{NaCl}$ solution was investigated by potentiodynamic polarization curve and electrochemical impedance spectroscopy (EIS), and the effect of copper diffusion on the corrosion resistance of carbon steel was discussed.

\section{Materials and Experiment Methods}

\subsection{Meterials}

The experiment substrate is carbon steel, its chemical composition is: C0.15, S0.02, Si0.10, P0.02, Mn1.20, and the balance is Fe. We define it as Fe in this article. According to the test requirements, the machined carbon steel size is $20 \mathrm{~mm} \times 20 \mathrm{~mm} \times 3 \mathrm{~mm}$. For the electrodeposition solution, $30 \mathrm{~g} / \mathrm{L} \mathrm{CuSO}_{4}+147 \mathrm{~g} / \mathrm{L} \mathrm{Na}_{3} \mathrm{C}_{6} \mathrm{H}_{5} \mathrm{O}_{7} \cdot 2 \mathrm{H}_{2} \mathrm{O}+\mathrm{C}_{4} \mathrm{H}_{4} \mathrm{KNaO}_{6} \cdot 4 \mathrm{H}_{2} \mathrm{O}$ $+20 \mathrm{~g} / \mathrm{L} \mathrm{NaHCO}_{3}+8 \mathrm{~g} / \mathrm{L} \mathrm{KHNO}_{3}$ were selected. The surface of the selected carbon steel was treated by polishing, alkali cleaning, acid cleaning and activation. Under the conditions of bath temperature $70{ }^{\circ} \mathrm{C}$, current density $5 \mathrm{~A} / \mathrm{dm}^{2}$ and bath $\mathrm{pH}$ value 11 , copper was electrodeposited on the surface of the selected carbon steel with copper plate as anode and 
carbon steel as cathode for $30 \mathrm{~min}$. The sample after electrodeposition was $\mathrm{Cu} / \mathrm{Fe}$. The $\mathrm{Cu} / \mathrm{Fe}$ was cleaned by ethanol and placed into a tube annealing furnace with high-purity argon gas. After heating to $1050{ }^{\circ} \mathrm{C}$ at a rate of $5^{\circ} \mathrm{C} / \mathrm{min}$, the $\mathrm{Cu} / \mathrm{Fe}$ was put into the furnace at constant temperature for $120 \mathrm{~min}$ and then pushed out of the furnace. The $\mathrm{Cu} / \mathrm{Fe}$ was rapidly cooled to room temperature in flowing argon gas to obtain a copper/carbon steel gradient material, defined as $\mathrm{Cu}-\mathrm{Fe}$. The $80 \% \mathrm{Cu}-\mathrm{Fe}$ with surface copper content of $80 \%$ was prepared by grinding and polishing the surface of the $\mathrm{Cu}-\mathrm{Fe}$ and destroying the surface copper layer. The $\mathrm{Fe}, \mathrm{Cu} / \mathrm{Fe}, \mathrm{Cu}-\mathrm{Fe}$ and $80 \% \mathrm{Cu}-\mathrm{Fe}$ were used as test samples, the process and characteristic of different materials was shown in Table 1. The surfaces were polished, wiped with ethanol, cleaned with distilled water, and dried. Except for the reserved working face $(10 \mathrm{~mm} \times 10 \mathrm{~mm})$, other surfaces were sealed with epoxy resin and curing agent with a mass ratio of 4:1.

Table 1. Process and characteristic of different materials.

\begin{tabular}{cccc}
\hline Name of the Sample & Process & $\begin{array}{c}\text { Surface Copper } \\
\text { Content/\% }\end{array}$ & $\begin{array}{c}\text { Thickness of the Diffusion } \\
\text { Layer/ } \mu \text { m }\end{array}$ \\
\hline $\mathrm{Fe}$ & - & 0 & 0 \\
$\mathrm{Cu} / \mathrm{Fe}$ & plating & 100 & 0 \\
$\mathrm{Cu}-\mathrm{Fe}$ & plating + diffusion annealing & 100 & 16 \\
$80 \% \mathrm{Cu}-\mathrm{Fe}$ & grinding and polishing the surface of the & 80 & 15 \\
& copper/carbon steel gradient material & & \\
\hline
\end{tabular}

\subsection{Experiment Procedure}

An Axiovert 200 Zeiss microscope and FEI Quanta 650 FEG field emission scanning electron microscope (SEM, FEI Company, Hillsboro, OR, USA) equipped with an energy dispersive spectrometer (EDS, FEI Company, Hillsboro, OR, USA) were used to analyse the cross-sectional microstructure and composition of $\mathrm{Cu}$-Fe prepared by the electrodepositiondiffusion method. The polarization curves and electrochemical impedance spectroscopy (EIS) were measured by an IM6ex electrochemical workstation (Zahner Kronach, Germany). A three-electrode system was used. The working electrode was the sample to be tested, the reference electrode was the saturated calomel electrode (SCE) and the auxiliary electrode was the platinum electrode. The corrosion solution was saturated $\mathrm{NaCl}$ solution with mass fraction of $3.5 \%$. The three-electrode system scheme of experiment apparatus is shown in Figure 1. The electrochemical corrosion test was carried out at room temperature. The working electrode was soaked in $3.5 \% \mathrm{NaCl}$ solution for $30 \mathrm{~min}$ before the test, and electrochemical measurement was performed after the open circuit potential was stabilized. Potentiodynamic polarization curves were obtained in the range of $-1.0 \sim 0.2 \mathrm{~V}$ (relative to SCE) at a scanning rate of $5 \mathrm{mV} / \mathrm{s}$. The electrochemical impedance spectroscopy (EIS) was performed at open circuit potential. The amplitude of the sinusoidal wave was $5 \mathrm{mV}$ and the frequency range was $0.01 \mathrm{~Hz} \sim 100 \mathrm{kHz}$. AC impedance spectra were analysed by ZSimDemo software. 


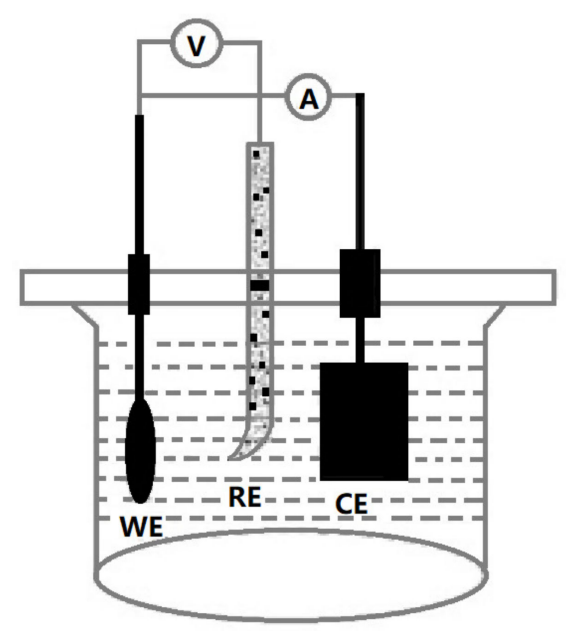

Figure 1. Three Electrode System Scheme of Experiment Apparatus.

\section{Results}

\subsection{Effect of Copper Diffusion on Microstructure of Carbon Steel}

Figure 2 is a cross-sectional microstructure of $\mathrm{Cu}$-Fe prepared by high-temperature annealing of a $\mathrm{Cu} / \mathrm{Fe}$ sample. Among them, the black spots in the plating layer are corrosion pits. As can be seen from Figure 1, after diffusion annealing at $1050{ }^{\circ} \mathrm{C}$, copper atoms on that surface of the carbon steel diffuse into the interior of the matrix, and copper is distributed more at the grain boundary of the carbon steel, indicating that the diffusion process of copper in the carbon steel is not a uniform diffusion, but proceeds along the grain boundary at first, and diffuses from the grain boundary to the interior of the grain (Figure 3). At that same time, after high-temperature diffusion annealing treatment, the grain size of carbon steel is obviously grow, but the grain size of copper diffusion region is obviously smaller than that of carbon steel, which shows that the diffusion of copper atoms restrains the grain growth behavior of carbon steel during high-temperature annealing, and plays the role of grain refinement, and the nearer the copper coating is, the more obvious the grain refinement is.

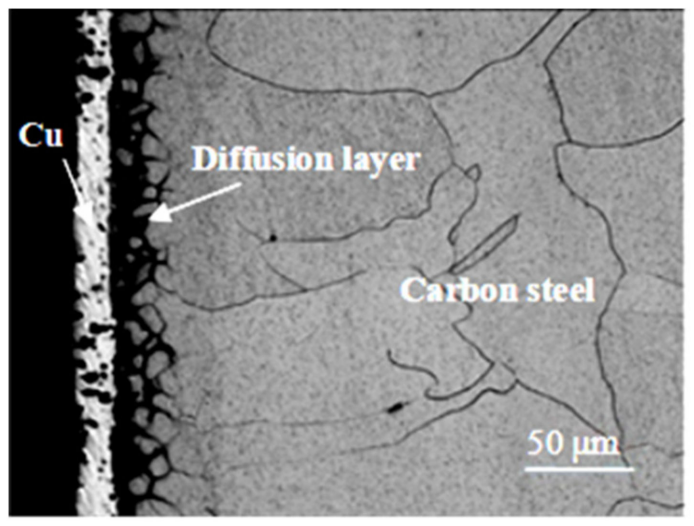

(a)

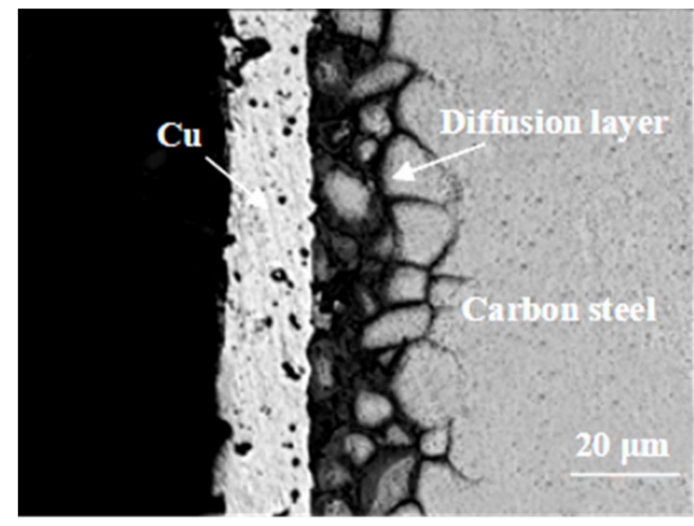

(b)

Figure 2. Microstructure of $\mathrm{Cu}-\mathrm{Fe}(\mathbf{a})$ Carbon steel and diffusion layer and (b) Diffusion layer. 


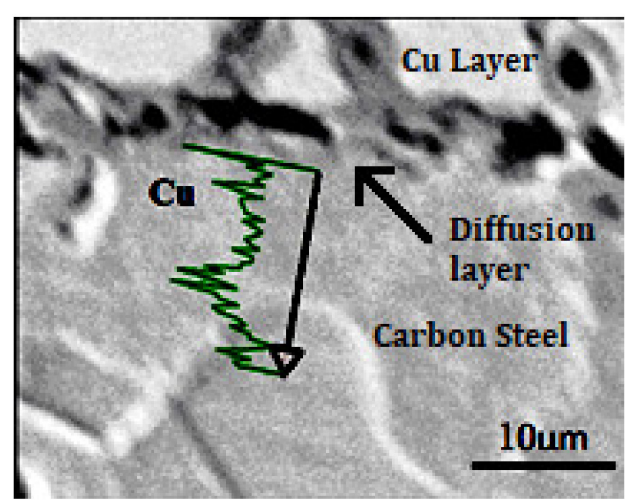

(a)

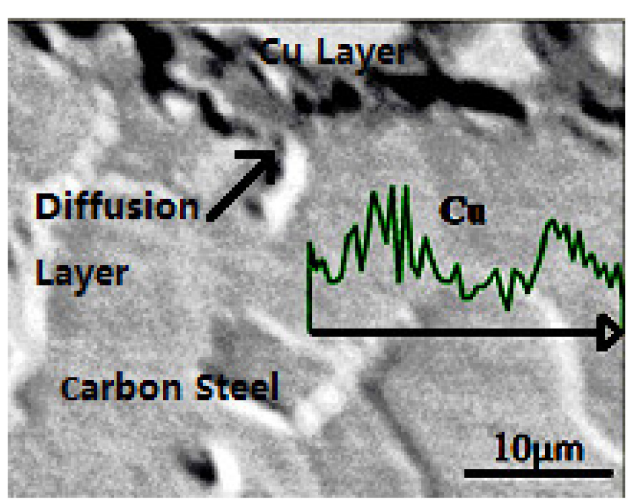

(b)

Figure 3. SEM image and EDS line scanning of grain boundary of $\mathrm{Cu}-\mathrm{Fe}(\mathbf{a})$ Longitudinal analysis and (b) Lateral analysis.

The variation of copper content along the depth of the sample is analyed by glow discharge spectrometer. The results are shown Figure 4. As shown in Figure 4, after the diffusion annealing treatment at high temperature, the copper atoms in the coating and the iron atoms in the carbon steel substrate interdiffuse, the copper and iron elements are obviously distributed in a gradient and the concentration of the copper elements decreases from the coating to the carbon steel interior, thereby realizing the metallurgical bonding between the coating and the carbon steel substrate.

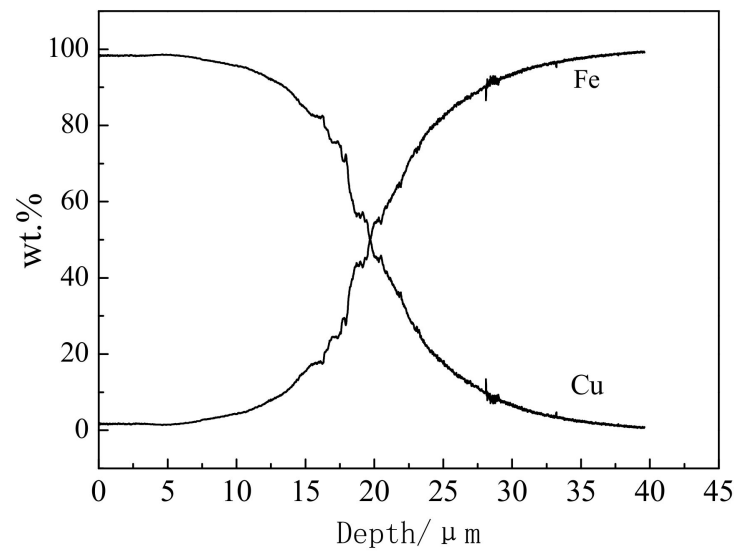

Figure 4. The content distribution of $\mathrm{Cu}$ in $\mathrm{Cu}-\mathrm{Fe}$ after annealing diffusion treatment at $1050{ }^{\circ} \mathrm{C}$.

\subsection{Polarization Curve}

Figure 5 shows the polarization curves of $\mathrm{Fe}, \mathrm{Cu} / \mathrm{Fe}, \mathrm{Cu}-\mathrm{Fe}$ and $80 \% \mathrm{Cu}-\mathrm{Fe}$ in $3.5 \%$ $\mathrm{NaCl}$ solution. Corrosion potential Ecorr, corrosion current density Icorr and cathode and anode Tafel slope $\beta c$ and $\beta$ a of different materials were obtained by Tafel extrapolation, and the results are shown in Table 2. Icorr is an important parameter to evaluate the corrosion reaction kinetics. It is usually proportional to the corrosion rate of the material in the corrosion medium $[10,11]$. The smaller Icorr is, the lower the corrosion reaction rate is and the stronger the corrosion resistance of the material is. As seen in Figure 5, $\mathrm{Fe}, \mathrm{Cu} / \mathrm{Fe}$, $80 \% \mathrm{Cu}-\mathrm{Fe}$ and $\mathrm{Cu}-\mathrm{Fe}$ have similar polarization behavior, that is, with the increase of applied potential, the corrosion current density increases, the dissolution rate of the material is higher than the passivation rate, the anodic polarization curves of the samples show active dissolution in the electrochemical corrosion process and no passivation reaction occurs on the surface of the samples to form a stable passivation film. At the same time, in the process of increasing corrosion potential, there is no passivation effect in the polarization process of different materials, which indicates that there is no serious pitting corrosion phenomenon in the electrochemical corrosion process, and all of them show the characteristics of uniform corrosion [12]. As can also be seen from Figure 5 and Table 2, the corrosion behavior of 
the $\mathrm{Cu}-\mathrm{Fe}$ is similar to that of the $\mathrm{Cu} / \mathrm{Fe}$ in $3.5 \% \mathrm{NaCl}$ solution, the polarization curves almost coincide, and Ecorr $(329 \mathrm{mV}, 333 \mathrm{mV})$, Icorr $\left(29.0 \mu \mathrm{A} / \mathrm{cm}^{2}, 30.6 \mu \mathrm{A} / \mathrm{cm}^{2}\right)$ are very close, which indicate that the corrosion resistance of $\mathrm{Cu}-\mathrm{Fe}$ is similar to that of $\mathrm{Cu} / \mathrm{Fe}$ prepared by electroplating method, that is, the corrosion resistance of the $\mathrm{Cu}$-Fe prepared by the electrodeposition-diffusion method is mainly obtain through a surface pure copper layer. However, the corrosion potential and corrosion current density of $80 \% \mathrm{Cu}-\mathrm{Fe}$ with are between $\mathrm{Fe}$ and $\mathrm{Cu}-\mathrm{Fe}$, and very close to $\mathrm{Cu} / \mathrm{Fe}$ material, and much different from carbon steel, which indicates that even if the copper layer on the gradient material surface is destroyed, the gradient material can still resist corrosion.

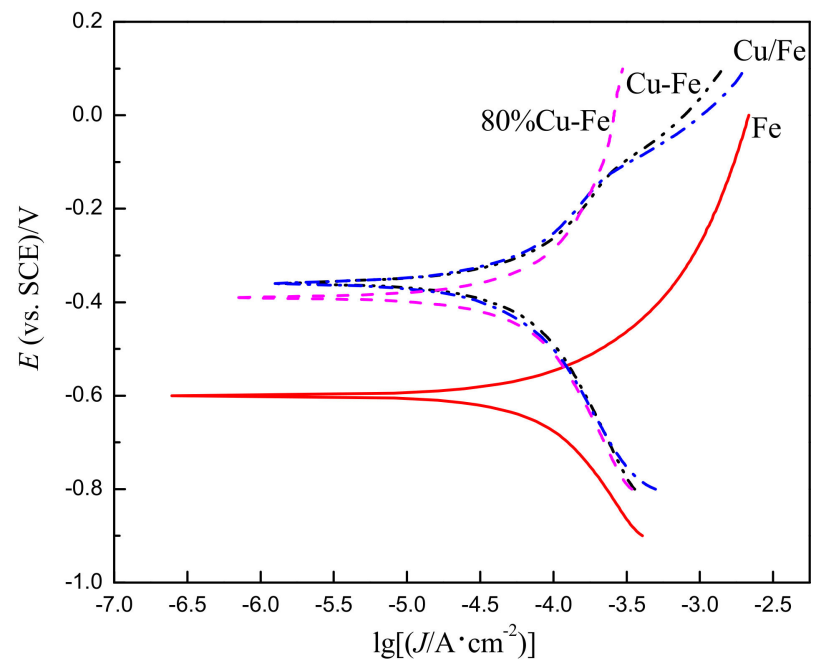

Figure 5. Polarization curves of carbon steel and $\mathrm{Cu}-\mathrm{Fe}$ alloy in $3.5 \% \mathrm{NaCl}$ solution.

Table 2. Fitting result of polarization curves for carbon steel and $\mathrm{Cu}-\mathrm{Fe}$ alloy in $3.5 \% \mathrm{NaCl}$ solution.

\begin{tabular}{ccccc}
\hline Sample & Ecorr $/ \mathbf{m V}(\mathrm{SCE})$ & Icorr $/\left(\boldsymbol{\mu} \mathbf{A} / \mathbf{c m}^{2}\right)$ & $\beta \mathrm{c} /(\mathbf{m V} / \mathbf{d e c})$ & $\beta \mathbf{a} /(\mathbf{m V} / \mathbf{d e c})$ \\
\hline$F e$ & -600 & 53.0 & 301 & 261 \\
$\mathrm{Cu} / \mathrm{Fe}$ & -357 & 29.0 & 333 & 252 \\
$\mathrm{Cu}-\mathrm{Fe}$ & -362 & 30.6 & 329 & 240 \\
$80 \% \mathrm{Cu}-\mathrm{Fe}$ & -389 & 49.0 & 455 & 500 \\
\hline
\end{tabular}

In addition, the anodic polarization curves are usually used to characterize the rate of potential forward movement and the tendency of passivation on the surface of the specimen during the electrochemical corrosion process. The smaller the Tafel slope of the anodic polarization curve, the flatter the curve, the lower the polarization degree of the material in the corrosion process, the higher the surface activity of the sample and the weaker the passivation tendency. As seen in Figure 5 and Table 2, compared with the anodic polarization curves of carbon steel, $\mathrm{Cu} / \mathrm{Fe}$ and $\mathrm{Cu}-\mathrm{Fe}$, the Tafel slope of the anodic polarization curves of $\mathrm{Cu}-\mathrm{Fe}$ / carbon steel gradient materials with copper content of $80 \%$ is higher, which indicates that the surface activity of $80 \% \mathrm{Cu}-\mathrm{Fe}$ is lower in the range of test potential, and there is an obvious passivation trend although no stable passivation film is formed. However, the $\mathrm{Fe}, \mathrm{Cu} / \mathrm{Fe}$ and $\mathrm{Cu}-\mathrm{Fe}$ were always activated, and the corrosion process was a continuous dissolution process without a passivation trend.

\subsection{EIS}

Figure 6 shows the electrochemical impedance spectra of $\mathrm{Fe}, \mathrm{Cu} / \mathrm{Fe}, 80 \% \mathrm{Cu}-\mathrm{Fe}$ and $\mathrm{Cu}-\mathrm{Fe}$ in $3.5 \% \mathrm{NaCl}$ solution. As can be seen from Figure 6, the electrochemical impedance curves of different materials are arc-shaped, capacitive resistance arcs are generated in the high-frequency region and no inductive resistance arcs are generated in the low-frequency region, and the corrosion process of different materials is a single time constant $[13,14]$, 
which indicates that no serious pitting corrosion occurs in the electrochemical corrosion process, and the control process of charge transfer is an electrochemical reaction $[15,16]$. In electrochemical impedance spectroscopy (EIS), the radius of capacitive resistance arc indicates the resistance of the material in charge-discharge and charge transfer process. The larger the diameter of capacitive resistance arc is, the larger the resistance of charge transfer is in active solution process, the more difficult the electrochemical reaction is and the stronger the corrosion resistance of the material is. As seen in Figure 6, $\mathrm{Cu} / \mathrm{Fe}$ and $\mathrm{Cu}-\mathrm{Fe}$ have similar capacitive arc diameters, and their corrosion resistance in $3.5 \% \mathrm{NaCl}$ solution is increased, their corrosion rate is decreased and their corrosion resistance is greatly enhanced compared with that of carbon steel. These results show that the corrosion behavior of $\mathrm{Cu} / \mathrm{Fe}$ and $\mathrm{Cu}$-Fe prepared by electrodeposition and high-temperature diffusion reaction is similar in the process of electrochemical corrosion and dissolution, and the corrosion resistance of $\mathrm{Cu} / \mathrm{Fe}$ is much higher than that of $\mathrm{Fe}$ in $3.5 \% \mathrm{NaCl}$ solution. In the electrochemical impedance spectroscopy (EIS) of $80 \% \mathrm{Cu}-\mathrm{Fe}$, the diameter of capacitive arc is between $\mathrm{Fe}$ and $\mathrm{Cu}-\mathrm{Fe}$, which indicates that the corrosion resistance of $\mathrm{Cu}-\mathrm{Fe}$ decreases after the surface copper layer is destroyed, but it is still better than carbon steel.

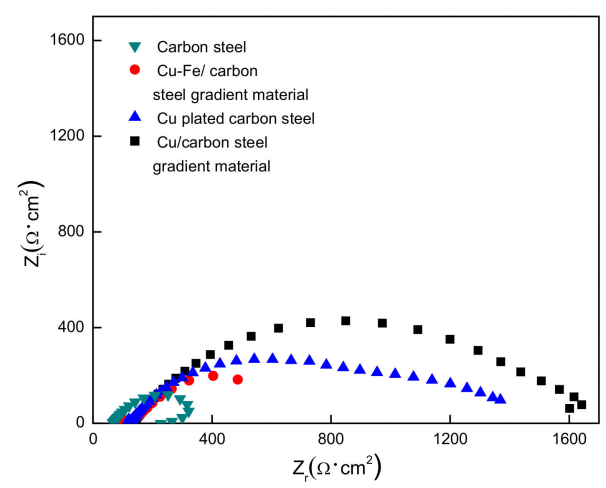

Figure 6. EIS of carbon steel and $\mathrm{Cu}-\mathrm{Fe}$ alloy in $3.5 \% \mathrm{NaCl}$ solution.

In order to study the kinetic parameters and electrochemical properties of $\mathrm{Fe}, \mathrm{Cu} / \mathrm{Fe}$, $80 \% \mathrm{Cu}-\mathrm{Fe}$ and $\mathrm{Cu}-\mathrm{Fe}$ in $3.5 \% \mathrm{NaCl}$ solution, the electrochemical impedance spectra of the materials were fitted by ZSimDemo software. The fitting results and equivalent fitting circuits are shown in Figure 7, where Rs is the equivalent resistance of the etching solution, $\mathrm{Q}$ is the constant phase angle component of the charge transfer between the electrode and the etching solution interface, the magnitude of which is related to the dielectric properties of the etching product layer, determined by the constant phase coefficient $\mathrm{Y}$ and the dispersion coefficient $\mathrm{n}, \mathrm{Ca}$ and $\mathrm{Ra}$ are the reaction capacitance and resistance of the charge at the etching interface, and the higher the Ra value, the more difficult the reaction between the etching ion and metal is; Rt is the charge transfer resistance [17], which is the characteristic parameter of corrosion rate. The higher the Rt value, the more difficult the corrosion of metal surface and the lower the corrosion rate of material [17-19]. Rp is the polarization resistance, and the value of $\mathrm{Rp}$ is the sum of Ra and Rt. The higher the Rp value, the stronger the corrosion resistance of the material is. The fitting parameters of electrochemical impedance spectra of different materials in $3.5 \% \mathrm{NaCl}$ solution at open circuit potential are shown in Table 3. As can be seen from Table 3, the carbon steel has the lowest Rt, Ra and Rp values, indicating that the carbon steel has the highest corrosion rate in $3.5 \% \mathrm{NaCl}$ solution and is prone to corrosion failure. After the $\mathrm{Cu} / \mathrm{Fe}$ was prepared by electrodeposition, the Rt and Ra increased to 974 and $258 \Omega \cdot \mathrm{cm}^{2}$, respectively, and the Rp increased to $1232 \Omega \cdot \mathrm{cm}^{2}$. The results showed that the copper layer on the surface of the carbon steel improved the corrosion resistance of the material in $3.5 \% \mathrm{NaCl}$ solution and slowed down the corrosion rate. As can also be seen from Table 3, after high-temperature heat treatment of that $\mathrm{Cu} / \mathrm{Fe}$ sample, the fitting parameter values of the electrochemical impedance spectra of the prepared $\mathrm{Cu}-\mathrm{Fe}$ are close to those of the $\mathrm{Cu} / \mathrm{Fe}$, and have similar corrosion behavior and corrosion resistance, indicating that the corrosion resistance of the 
$\mathrm{Cu}-\mathrm{Fe}$ is mainly obtained based on the surface pure copper layer. When the copper layer on the surface is destroyed to form a copper-iron alloy/carbon steel gradient material with a surface copper content of $80 \%$, the Rt, Ra and $\mathrm{Rp}$ values of the materials decreased to 163,186 and $349 \Omega \cdot \mathrm{cm}^{2}$, respectively, and its size is between that fit value of carbon steel and copper-iron alloy/carbon steel gradient material. The results show that the corrosion resistance of the $80 \% \mathrm{Cu}$-Fe with a damaged copper layer decreases in $3.5 \% \mathrm{NaCl}$ solution, but the corrosion rate of the $80 \% \mathrm{Cu}$-Fe is still lower than that of the original carbon steel material, and the corrosion resistance of the $80 \% \mathrm{Cu}-\mathrm{Fe}$ is stronger than that of the $\mathrm{Fe}$, which is consistent with the results of the polarization curves.

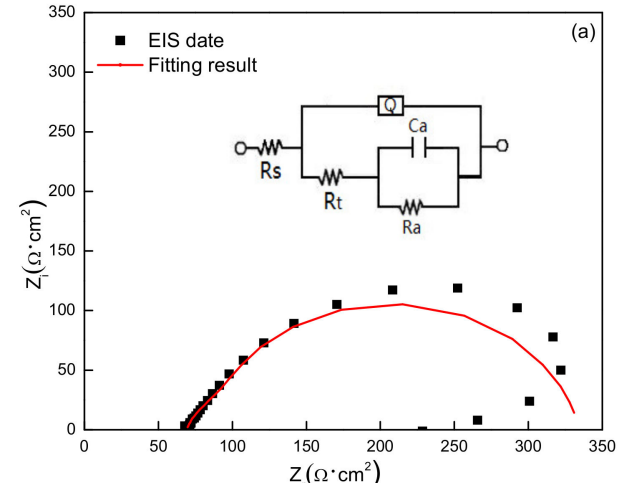

(a)

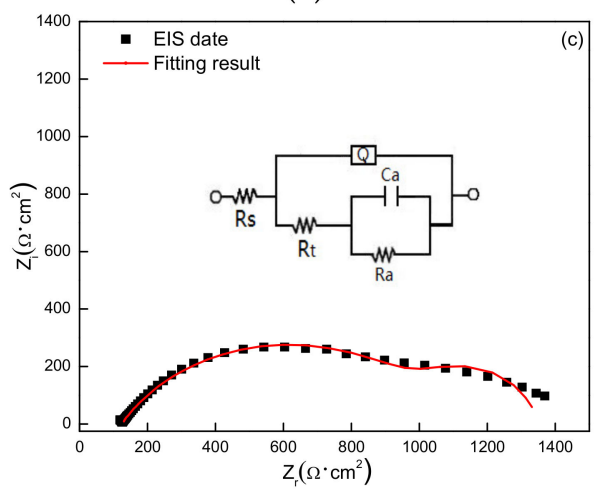

(c)

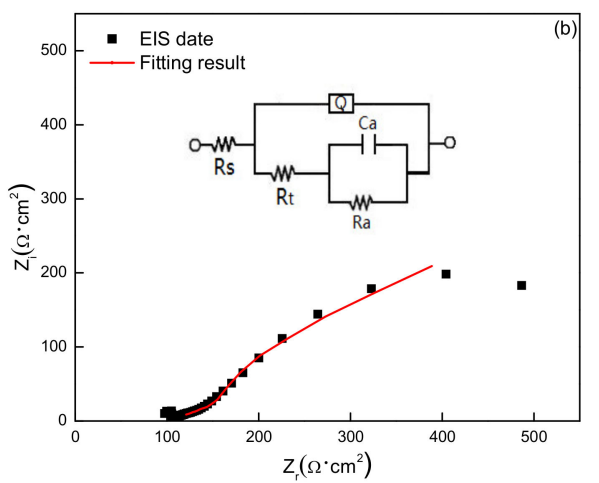

(b)

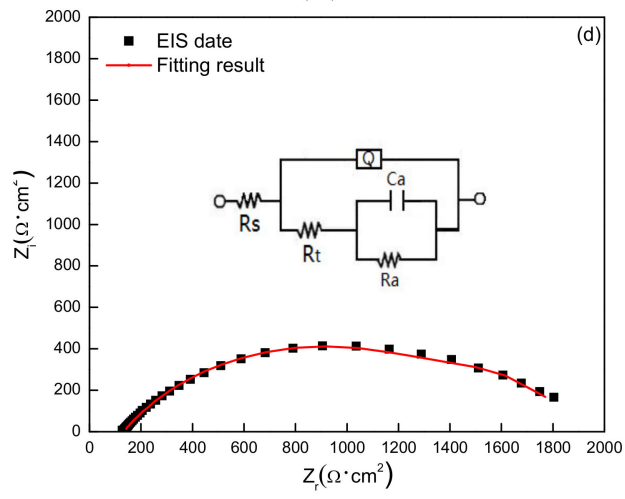

(d)

Figure 7. EIS plots and fitting results of different materials in $3.5 \% \mathrm{NaCl}$ solution (a) Fel, (b) $80 \% \mathrm{Cu}-\mathrm{Fe}$ (c) $\mathrm{Cu} / \mathrm{Fe}(\mathrm{d}) \mathrm{Cu}-\mathrm{Fe}$.

Table 3. Fitting result of EIS for carbon steel and $\mathrm{Cu}-\mathrm{Fe}$ alloy in $3.5 \% \mathrm{NaCl}$ solution.

\begin{tabular}{cccccc}
\hline Sample & $\mathbf{R s} / \mathbf{\Omega} \cdot \mathbf{c m}^{\mathbf{2}}$ & $\mathbf{R t} / \mathbf{\Omega} \cdot \mathbf{c m}^{\mathbf{2}}$ & $\mathbf{C a} / \mathbf{F} \cdot \mathbf{c m}^{\mathbf{2}}$ & $\mathbf{R a} / \mathbf{\Omega} \cdot \mathbf{c m}^{\mathbf{2}}$ & $\mathbf{R p} / \mathbf{\Omega} \cdot \mathbf{c m}^{\mathbf{2}}$ \\
\hline $\mathrm{Fe}$ & 69 & 84 & $8.27 \times 10^{-3}$ & 182 & 266 \\
$\mathrm{Cu} / \mathrm{Fe}$ & 129 & 1539 & $9.48 \times 10^{-3}$ & 203 & 1742 \\
$\mathrm{Cu}-\mathrm{Fe}$ & 121 & 974 & $4.21 \times 10^{-3}$ & 258 & 1232 \\
$80 \% \mathrm{Cu}-\mathrm{Fe}$ & 103 & 163 & $2.23 \times 10^{-3}$ & 186 & 349 \\
\hline
\end{tabular}

\subsection{Surface Morphology of Materials after Polarization}

Figure 8 is SEM of the surface morphology of $\mathrm{Fe}, 80 \% \mathrm{Cu}-\mathrm{Fe}, \mathrm{Cu} / \mathrm{Fe}$ and $\mathrm{Cu}-\mathrm{Fe}$ after polarization test in $3.5 \% \mathrm{NaCl}$ solution, respectively. As seen in Figure 8, The surface of different materials was corroded to varying degrees in the process of electrochemical corrosion. Among them, the surface corrosion of Fe after polarization is more serious, and slight pitting corrosion occurs locally. The surface corrosion of $80 \% \mathrm{Cu}-\mathrm{Fe}, \mathrm{Cu} / \mathrm{Fe}$ and $\mathrm{Cu}$-Fe after polarization is much lower than that of $\mathrm{Fe}$, and the corrosion products on the surface of the material are uniformly distributed without pitting corrosion. 



Figure 8. SEM images of carbon steel and $\mathrm{Cu}-\mathrm{Fe}$ alloy after potentiodynamic polarization in $3.5 \%$ $\mathrm{NaCl}$ solution, (a) $\mathrm{Fe}($ b) $80 \% \mathrm{Cu}-\mathrm{Fe}(\mathbf{c}) \mathrm{Cu} / \mathrm{Fe}$, (d) $\mathrm{Cu}-\mathrm{Fe}$.

Table 4 shows the surface composition analysis of different materials after polarization tests in $3.5 \% \mathrm{NaCl}$ solution. As shown in Table 4, compared to $\mathrm{Fe}$, the content of oxygen in the corrosion zone of $\mathrm{Cu} / \mathrm{Fe}$ and $\mathrm{Cu}-\mathrm{Fe}$ with pure copper on the surface is decreased. At the same time, the composition of the corrosion product on the surface of the two materials after polarization reaction is close to each other, which indicates that the corrosion resistance of the $\mathrm{Cu} / \mathrm{Fe}$ and the $\mathrm{Cu}-\mathrm{Fe}$ is similar to that of the $\mathrm{Fe}$, and the corrosion product $\left(\mathrm{Fe}_{2} \mathrm{O}_{3}\right.$, $\mathrm{Cu}_{2} \mathrm{O}$ ) generated in the electrochemical corrosion process is reduced, the corrosion degree is reduced and the corrosion resistance is clearly enhanced. The content of oxygen in the corrosion zone of $80 \% \mathrm{Cu}-\mathrm{Fe}$ containing $80 \%$ copper is between carbon steel and $\mathrm{Cu} / \mathrm{Fe}$ and $\mathrm{Cu}-\mathrm{Fe}$, which indicates that the corrosion resistance of $\mathrm{Cu} / \mathrm{Fe}$ gradient material in 3.5\% $\mathrm{NaCl}$ solution is still better than that of carbon steel, which is consistent with the results of polarization curve and AC impedance spectroscopy.

Table 4. Surface composition analysis of different materials after potentiodynamic polarization in $3.5 \% \mathrm{NaCl}$ solution.

\begin{tabular}{cccc}
\hline Sample & $\mathbf{O} / \%$ & $\begin{array}{c}\text { Mass Fraction/\% } \\
\mathbf{C u} / \%\end{array}$ & $\mathbf{F e} / \%$ \\
\hline $\mathrm{Fe}$ & 11.27 & 0 & 88.73 \\
$\mathrm{Cu} / \mathrm{Fe}$ & 2.94 & 97.06 & 0 \\
$\mathrm{Cu}-\mathrm{Fe}$ & 3.06 & 96.94 & 0 \\
$80 \% \mathrm{Cu}-\mathrm{Fe}$ & 6.97 & 75.87 & 17.16 \\
\hline
\end{tabular}

\section{Discussion}

The corrosion potential Ecorr $(-600 \mathrm{mV}(\mathrm{SCE}))$ and charge transfer resistance $\mathrm{Rt}\left(84 \Omega \cdot \mathrm{cm}^{2}\right)$ of carbon steel are the lowest and its corrosion current density Icorr $\left(53.0 \mu \mathrm{A} / \mathrm{cm}^{2}\right)$ is the highest, and the surface corrosion degree of carbon steel is high, so slight pitting corrosion occurs; that is, the carbon steel is easily corroded in $3.5 \% \mathrm{NaCl}$ solution. This is because $\mathrm{Cl}^{-}$in the corrosion solution is a corrosive ion, because of its small ion radius, it is easy to accumulate and adsorb on the surface of carbon steel grain boundaries, defects and 
other places, thus destroying the surface film, making the metal constantly exposed and in contact with the corrosion solution corrosion reaction, and inducing the corrosion behavior of carbon steel $[20,21]$. As shown in Tables 2 and 3, the corrosion potential $(-357 \mathrm{mV})$, charge transfer resistance $\left(974 \Omega \cdot \mathrm{cm}^{2}\right)$ and corrosion current density $\left(29.0 \mu \mathrm{A} / \mathrm{cm}^{2}\right)$ of the material increase, and the corrosion resistance of the $\mathrm{Cu} / \mathrm{Fe}$ is obviously enhance after the $\mathrm{Cu} / \mathrm{Fe}$ is prepare by electroplating a layer of copper on the surface of the carbon steel by the electrodeposition treatment. This is due to the fact that the surface of carbon steel after copper plating is composed of a pure copper layer, while the metal copper has stable thermodynamic properties and higher standard electrode potential. The corrosion rate is lower and the corrosion resistance is stronger in $3.5 \% \mathrm{NaCl}$ solution, and the contact between carbon steel and corrosion medium is hindered, so the corrosion resistance of carbon steel material is enhanced. However, it is difficult to prepare $\mathrm{Cu} / \mathrm{Fe}$ by electroplating in order to enhance the corrosion resistance of carbon steel. On the one hand, the metallurgical combination of copper coating and carbon steel is not realized in the electroplating process, resulting in low adhesion between the copper coating and substrate, and a coating that is easy to abrade off in the process of use. On the other hand, as can be seen from Figure 4 and Table 2, the corrosion potential of the copper layer is more positive than that of the carbon steel substrate, and the copper layer is a typical cathode coating layer. As soon as the copper layer is partially destroyed, exposing the carbon steel substrate, in corrosive environment, because of negative electrode potential, the carbon steel substrate becomes anode and the copper coating as cathode will form a large cathode and small anode on the surface of the material. At this time, the copper coating is not only insufficient to effectively hinder the corrosion reaction, but also causes more serious local corrosion of the exposed part of carbon steel.

When the $\mathrm{Cu} / \mathrm{Fe}$ is annealed at $1050{ }^{\circ} \mathrm{C}$, the copper-coated layer will diffuse into the carbon steel due to the high temperature to form the copper/carbon steel gradient material with a pure copper surface and a copper concentration decreasing from surface to interior. As can be seen from a Cu-Fe binary alloy phase diagram [22], $\mathrm{Cu}$ and Fe are a binary alloy, infinitely soluble in liquid state and finitely soluble in solid state. The solid solubility of copper atoms in $\mathrm{Fe}$ is less than $5 \%$ at the experimental heat treatment temperature $\left(1050{ }^{\circ} \mathrm{C}\right)$, and a segregation phase is for in the carbon steel when the concentration of copper atoms in the diffusion layer exceeds its solid solubility. In the diffusion process, the segregation phase occupies the dislocation, vacancy and other defects in the Fe atom in the carbon steel. As can be seen from Figure 2, after high-temperature annealing at $1050{ }^{\circ} \mathrm{C}$, copper atoms on the surface of the $\mathrm{Cu} / \mathrm{Fe}$ diffuse into the carbon steel, and copper segregation phases gather at the inner grain boundaries of the carbon steel and play a pinning role on the grain boundaries of the carbon steel, inhibiting the growth of the carbon steel grains during high-temperature annealing and refining the grains. As the surface is compose of copper, the corrosion behavior of the $\mathrm{Cu}-\mathrm{Fe}$ is similar to that of the $\mathrm{Cu} / \mathrm{Fe}$, and the corrosion resistance of the Fe substrate is greatly enhance by the action of pure copper on the surface. At that same time, the corrosion resistance of the $80 \% \mathrm{Cu}-\mathrm{Fe}$ with $80 \%$ copper content is lower than that of the $\mathrm{Cu}-\mathrm{Fe}$, but still better than that of the original carbon steel. When the surface of the $\mathrm{Cu}-\mathrm{Fe}$ is damaged by polishing and destroy the copper layer by polishing, the corrosion resistance of the $80 \% \mathrm{Cu}-\mathrm{Fe}$ is also lower than that of the original carbon steel. On the one hand, copper atoms diffuse into the carbon steel, and copper segregation phases which exceed the solid solubility accumulate at the grain boundaries and defects of the carbon steel, thus inhibiting the adsorption and accumulation of erosive $\mathrm{Cl}^{-}$on the surface of the carbon steel and the corrosion reaction. On the other hand, copper precipitates on the surface of carbon steel, as a result, the polarization curves show that the Tafel slope of $80 \% \mathrm{Cu}-\mathrm{Fe}$ anodes is higher, and there is no stable passivation film on the surface of the anodes during corrosion, but there is an obvious tendency of passivation. The results show that, in the $\mathrm{Cu}-\mathrm{Fe}$, the copper plating layer is metallurgically combined with the carbon steel, which enhances the wear resistance of the copper plating layer. At the same time, the diffusion of copper atoms and the segregation and precipitation of 
copper atoms in carbon steel can avoid the aggravation of severe local corrosion after the local destruction of the copper layer on the surface of the material, and further enhance the continuous corrosion resistance of carbon steel in a corrosive environment.

\section{Conclusions}

1. As for the $\mathrm{Cu}-\mathrm{Fe}$, during the electrodeposition-diffusion process, the copper coating on the surface of carbon steel will diffuse mainly along the grain boundary to the inside of carbon steel, and the diffusion of copper will restrain the grain growth of carbon steel during high-temperature heat treatment.

2. The corrosion current density $\left(30.6 \mu \mathrm{A} / \mathrm{cm}^{2}\right)$ of $\mathrm{Cu}-\mathrm{Fe}$ prepared by the electrodepositiondiffusion process is smaller than that of carbon steel $\left(53.0 \mu \mathrm{A} / \mathrm{cm}^{2}\right)$, meaning that the corrosion rate of $\mathrm{Cu}-\mathrm{Fe}$ is lower. The polarization resistance $\left(1742 \Omega \cdot \mathrm{cm}^{2}\right)$ of the $\mathrm{Cu}-\mathrm{Fe}$ is obviously higher than that of the carbon steel $\left(266 \Omega \cdot \mathrm{cm}^{2}\right)$, indicating that the corrosion resistance of the $\mathrm{Cu}-\mathrm{Fe}$ is stronger than that of the carbon steel material. The corrosion resistance of the $\mathrm{Cu}-\mathrm{Fe}$ is mainly obtained through a pure copper layer on the surface of the $\mathrm{Cu}-\mathrm{Fe}$.

If the copper layer on the surface of $\mathrm{Cu}-\mathrm{Fe}$ is destroyed, $80 \% \mathrm{Cu}-\mathrm{Fe}$ is obtained. The corrosion resistance of the $80 \% \mathrm{Cu}-\mathrm{Fe}$ is lower than that of the $\mathrm{Cu}-\mathrm{Fe}$, but it is still better than that of the $\mathrm{Fe}$, and the corrosion resistance of the $80 \% \mathrm{Cu}-\mathrm{Fe}$ shows an obvious passivation tendency in the corrosion process, indicating that even if the copper layer on the $\mathrm{Cu}-\mathrm{Fe}$ surface is destroyed, the gradient material can still resist corrosion.

Author Contributions: Conceptualization, T.M. and Y.L.; methodology, T.M., J.G. and H.L.; writingoriginal draft preparation, T.M.; writing—review and editing, T.M. and Y.L. formal analysis and validation, T.M., J.G. and Y.L.; project administration, Y.L.; funding acquisition, Y.L.; and supervision, Y.L. All authors have read and agreed to the published version of the manuscript.

Funding: This research was funded by National Natural Science Foundation of China grant number 51774142 .

Data Availability Statement: Data is contained within the article.

Acknowledgments: This work was financially supported by grants through the National Natural Science Foundation of China (Nos. 51774142).

Conflicts of Interest: The authors declare no conflict of interest.

\section{References}

1. Jafari, E. Improving the Corrosion Resistance of Carbon Steel by Ni-P Nano-Structured Coating. Russ. J. Electrochem. 2021, 57, 663-670. Available online: https://link.springer.com/article/10.1134/S1023193520120083 (accessed on 12 July 2021). [CrossRef]

2. Karim, M.; Daniel, S.; Haq, E.U.; Ahmad, A.A.; Khan, K.; Raza, S. Improving the Corrosion Resistance of API X56 and API X70 Pipeline Steels by Hot Dip Aluminization. Key Eng. Mater. 2021, 875, 315-321. Available online: https://www.scientific.net/KEM. 875.315 (accessed on 1 February 2021). [CrossRef]

3. Burduhos-Nergis, D.P.; Vizureanu, P.; Sandu, A.V.; Bejinariu, C. Phosphate Surface Treatment for Improving the Corrosion Resistance of the C45 Carbon Steel Used in Carabiners Manufacturing. Materials 2020, 13, 3410. Available online: https://www.researchgate.net/publication/343397480_Phosphate_Surface_Treatment_for_Improving_the_Corrosion_ Resistance_of_the_C45_Carbon_Steel_Used_in_Carabiners_Manufacturing (accessed on 1 August 2020). [CrossRef] [PubMed]

4. Liu, R.; Chen, X.P.; Wang, X.D.; Shi, Q.N. Effect of alloy elements on corrosion resistance of weathering steels in marine atmosphere environment. Hot Work. Technol. 2014, 43, 19-22. Available online: http:/ / en.cnki.com.cn/Article_en/CJFDTOTAL-SJGY2014200 05.htm (accessed on 21 October 2014).

5. Yue, L.J.; Wang, L.M.; Han, J.S. Effects of rare earth on inclusions and corrosion resistance of 10PCuRE weathering steel. J. Rare Earths 2010, 28, 952-956. Available online: https:/ / www.sciencedirect.com/science/article/pii/S1002072109602192 (accessed on 1 December 2010). [CrossRef]

6. Ren, F. Effect of niobium content on microstructure and properties of rolling weathering steel for construction. Hot Work. Technol. 2016, 45, 156-161. Available online: http:/ / en.cnki.com.cn/Article_en/CJFDTotal-SJGY201608020.htm (accessed on 8 July 2016).

7. Morcillo, M.; Diza, I.; Chico, B.; Cano, H.; de la Fuente, D. Weathering steels: From empirical development to scientific design. A review. Corros. Sci. 2014, 83, 6-31. Available online: https://www.sciencedirect.com/science/article/pii/S0010938X14001103 (accessed on 1 June 2014). [CrossRef] 
8. Chen, X.H.; Dong, J.H.; Han, E.H.; Wei, K.E. Effect of Cu, Mn on the corrosion performance of carbon steels in wet/dry environments. Mater. Prot. 2007, 40, 19-22. Available online: http:/ /en.cnki.com.cn/Article_en/CJFDTOTAL-CLBH200710008 htm (accessed on 15 October 2007).

9. Cen, S.B.; Chen, H.; Liu, Y.; Ma, Y.; Wu, Y. Effect of $\mathrm{CeO}_{2}$ on corrosion behavior of WC-12Co coatings by high velocity oxygen fuel. Acta Metall. Sin. 2016, 52, 1441-1448. Available online: https:/ /www.researchgate.net/publication/311640009_Effect_of_ CeO2_on_corrosion_behavior_of_WC-12Co_coatings_by_high_velocity_oxygen_fuel (accessed on 1 November 2016).

10. Liu, S.; Yue, C.; Chen, X.; Zhu, Q.; Tu, Y. Pitting Corrosion Resistance on Annealing Treated Super Duplex Stainless Steel S32750. Crystals 2020, 10, 294. Available online: https://www.mdpi.com/2073-4352/10/4/294 (accessed on 24 March 2020). [CrossRef]

11. Sherif, E.-S.M.; El Rayes, M.M.; Abdo, H.S. $\mathrm{Cr}_{3} \mathrm{C}_{2}$-NiCr Coating for the Protection of API Steel Corrosion in Concentrated Sodium Chloride Solution. Crystals 2020, 10, 249. Available online: https://www.mdpi.com/2073-4352/10/4/249 (accessed on 24 February 2020). [CrossRef]

12. Chen, C.Y.; Xiang, S.; Hu, Y.N.; Liang, Y.; Shi, W. Electrochemical behavior of SAF2507 in high temperature concentrated phosphoric acid. Mater. Rev. 2016, 30, 62-66. Available online: http:/ / en.cnki.com.cn/Article_en/CJFDTOTAL-CLDB201620015 .htm (accessed on 25 October 2016).

13. Li, L.; Yang, M.; Zhang, J. Effects of magnetron sputtering Ti films on wear resistance and corrosion resistance of AZ91 magnesium alloy. Surf. Technol. 2018, 47, 172-175. Available online: http://en.cnki.com.cn/Article_en/CJFDTotal-BMJS201803029.htm (accessed on 20 March 2018).

14. Zhang, X.; Wen, J.X.; Liu, Y.X.; Yang, X.M. Corrosion inhibition effect of galium aparine linn extracts on Q235 steel in hydrochloric acid solution. Surf. Technol. 2018, 47, 231-236. Available online: http://en.cnki.com.cn/Article_en/CJFDTotal-BMJS201803038 .htm (accessed on 20 March 2018).

15. Song, G.L.; Cao, C.N.; Lin, H.C. General circuit for EIS of an irreversible electrode under electrochemical step control and parameters analysis of the circuit. J. Chin. Soc. Corros. Prot. 1994, 8, 113-122. Available online: http://en.cnki.com.cn/Article_en/ CJFDTotal-ZGFF402.002.htm (accessed on 30 June 1994).

16. Xie, F.; Wang, D.; Wu, M.; Li, R. Effect of sulfate reducing bacteria in seawater on corrosion behavior of Q235 steel. Mater. Rev. 2017, 31, 51-55. Available online: https://www.researchgate.net/publication/323682629_Effect_of_Sulfate_Reducing_Bacteria_ in_Seawater_on_Corrosion_Behavior_of_Q235_Steel (accessed on 1 April 2017).

17. Li, X.; Yan, B.; Dong, P. Crystallization and electrochemical corrosion behaviors of amorphous and nanocrystal line Fe-based alloys. Electrochemistry 2009, 15, 269-274. Available online: https: / www.researchgate.net/publication/339276812_Crystallization_and_ electrochemical_corrosion_behaviors_of_nanometer_amorphous_Ni-P_alloys (accessed on 1 February 2020).

18. Liu, Z.Y.; Li, X.G.; Cheng, Y. Understand the occurrence of pitting corrosion of pipeline carbon steel under cathodic polarization. Electrochim. Acta 2012, 60, 259-263. Available online: https://www.sciencedirect.com/science/article/pii/S0013468611017245 (accessed on 15 January 2012). [CrossRef]

19. Wan, Y.; Zhang, D.; Liu, H.Q.; Li, Y.J.; Hou, B.R. Influence of sulphate-reducing bacteria on environmental parameters and marine corrosion behavior of Q235 steel in aerobic conditions. Electrochim. Acta 2010, 55, 1528-1534. Available online: https: //www.sciencedirect.com/science/article/pii/S0013468609012821 (accessed on 1 February 2010). [CrossRef]

20. Zhang, J.; Liu, F.L.; Li, W.H.; Duan, J.Z.; Hou, B.R. Effects of srb on corrosion of Zn-Al-Cd anode in marine sediment. Acta Metall. Sin. 2010, 46, 1250-1257. Available online: http:/ / en.cnki.com.cn/Article_en/CJFDTOTAL-JSXB201010015.htm (accessed on 11 October 2010). [CrossRef]

21. Gao, N.; Wang, C.; Zhang, F.H.; Li, F.; Zhao, S.L.; Li, P. The influence of major ions on the corrosion of penetrating zinc steel in oil field water. J. Petrochem. Univ. 2011, 24, 31-34. Available online: http:/ /www.en.cnki.com.cn/Article_en/CJFDTOTAL-SYHX201 103008.htm (accessed on 15 June 2011).

22. Ma, T.; Li, H.R.; Gao, J.X.; Li, Y.G. Diffusion behavior of $\mathrm{Cu}$ in carbon steel and its influence on corrosion resistance of carbon steel. Chin. J. Mater. Res. 2019, 33, 225-231. Available online: https:/ /www.researchgate.net/publication/333563173_Diffusion_ Behavior_of_Cu_in_Carbon_Steel_and_Its_Influence_on_Corrosion_Resistance_of_Carbon_Steel (accessed on 25 March 2019). 